\title{
Toxicity of Bacillus thuringiensis at different larval ages of Agrotis ipsilon (Lepidoptera: Noctuidae)
}

\author{
Toxicidade de Bacillus thuringiensis a diferentes idades de lagartas de Agrotis ipsilon \\ (Lepidoptera: Noctuidae)
}

\section{Ingrid Schimidt Kaiser ${ }^{1}$, Victor Luiz Souza Lima ${ }^{1 *}$, Dirceu Pratissoli ${ }^{1}$, Lorena Contarini Machado ${ }^{1}$, Regiane Cristina Oliveira de Freitas Bueno ${ }^{2}$}

\author{
${ }^{1}$ Universidade Federal do Espírito Santo, Alegre, ES, Brasil. *Author for correspondence: victor.souzalima@gmail.com. \\ ${ }^{2}$ Universidade Estadual Paulista, Botucatu, SP, Brasil.
}

Submission: 08/06/2018 / Acceptance: 10/12/2019

\begin{abstract}
The black cutworm Agrotis ipsilon (Hufnagel) (Lepidoptera: Noctuidae) is a cosmopolitan and polyphagous pest that attacks diverse crops and weed. One of the alternatives to insecticides may be the use of bioinsecticides based on Bacillus thuringiensis Berliner (Bt). Thus, the objective of the present study were evaluating the toxicity of Agree ${ }^{\circledR}$ and Dipel ${ }^{\circledR}$ bioinsecticides based on Bt on different larval ages of $A$. ipsilon. For the experiments, five larval ages were used (0-24, 48-72, 96-120, 144-168, and 192-216 h). The $A$. ipsilon caterpillars were individualized in acrylic tubes containing an artificial diet and $50 \mu \mathrm{L}$ of each biopesticide in the concentration $1 \times 10^{8}$ spores $\mathrm{mL}^{-1}$. Mortality was assessed for seven days. The two bioinsecticides evaluated promoted mortality at all larval ages of $A$. ipsilon. The age of $0-24 \mathrm{~h}$ had mortality above $90 \%$. The values of $\mathrm{LC}_{50}$ and $\mathrm{LC}_{90}$ were $9.8 \times 10^{5}$ and $7.4 \times 10^{6}$ spores $\mathrm{mL}^{-1}$ for Agree ${ }^{\circledast}$ and $1.3 \times$ $10^{6}$ e $1.4 \times 10^{7}$ spores $\mathrm{mL}^{-1}$ for Dipel ${ }^{\circledast}$, respectively, without difference between $L^{-1} C_{50}$ and $L^{2} C_{90}$ values of the bioinsecticides. The results indicate that younger caterpillars are more susceptible to Bt-based bioinsecticides.
\end{abstract}

KEYWORDS: biological control, bioinsecticide, black cutworm, lethal concentration, microbial control.

\section{RESUMO}

A lagarta rosca Agrotis ipsilon (Hufnagel) (Lepidoptera: Noctuidae) é uma praga cosmopolita e polífaga que ataca diversas culturas e plantas daninhas. Uma das alternativas de manejo ao uso de inseticidas químicos pode ser o uso de bioinseticidas à base de Bacillus thuringiensis Berliner (Bt). Deste modo, o presente trabalho teve por objetivo avaliar a toxicidade dos bioinseticidas Agree $^{\circledast}$ e Dipel ${ }^{\circledR}$ à base de $\mathrm{Bt}$ sobre diferentes idades de lagartas de $A$. ipsilon. Para os experimentos, lagartas de cinco idades foram utilizadas (0-24, 48-72, 96-120, 144-168 e 192-216 horas). As lagartas de A. ipsilon foram individualizadas em tubos de acrílico contendo dieta artificial e $50 \mu \mathrm{L}$ de cada bioinseticida na concentração $1 \times 10^{8}$ esporos $\mathrm{mL}^{-1}$. A mortalidade foi avaliada durante sete dias. Os dois bioinseticidas avaliados promoveram mortalidade em todas as idades das lagartas de $A$. ipsilon. Lagartas com idade $0-24 \mathrm{~h}$ apresentaram mortalidade acima de $90 \%$. Os valores de $\mathrm{CL}_{50}$ e $\mathrm{CL}_{90}$ foram $9,8 \times 10^{5}$ e $7,4 \times 10^{6}$ esporos $\mathrm{mL}^{-1}$ para Agree $^{\circledR}$ e $1,3 \times 10^{6}$ e $1,4 \times 10^{7}$ esporos $\mathrm{mL}^{-1}$ para Dipe ${ }^{\circledR}$, respectivamente, sem diferença entre os valores de $\mathrm{CL}_{50}$ e $\mathrm{CL}_{90}$ dos bioinseticidas. Os resultados indicam que lagartas mais jovens são mais suscetíveis aos bioinseticidas à base de $\mathrm{Bt}$.

PALAVRAS-CHAVE: controle biológico, bioinseticida, lagarta rosca, concentração letal, controle microbiano.

The black cutworm Agrotis ipsilon (Lepidoptera: Noctuidae) is a pest found worldwide attacking more than 30 important crops, such as maize, potatoes, beans, cabbage, coffee and tomatoes (BOUGHTON et al. 2001, FERNANDES et al. 2013). At the beginning of development, the caterpillars scrape the tissue of young leaves, and when they are more developed, they section the stem of the seedlings, close to the soil surface, that can cause the death of the plants (LINK \& COSTA 1984). The black cutworm is considered difficult to control because it is an insect of nocturnal habit, which makes it difficult to see in the field during the day. Also, it has a habit of being buried or below cultural remains, close to the plants that attack during the day 
(LINK \& COSTA 1984, LI et al. 2002).

Among the control alternatives for the black cutworm is biological control. The use of biotic agents to regulate the pest population is becoming increasingly important within the integrated pest management strategy as it aims at sustainable agriculture with less interference with the environment and human health (PARRA et al. 2002).

Among the widely used biological agents is the entomopathogenic bacterium Bacillus thuringiensis Berliner (Bt), which causes toxicity on several insects, being more efficient in the order Lepidoptera. Also, it is of great importance, mainly because it does not present toxicity to mammals, natural enemies, and does not affect crops (IBRAHIM et al. 2010, SANAHUJA et al. 2011). However, the toxicity of Bt bacteria varies between species of insects and between larval ages (ALINIA et al. 2000, MORAES \& FOERSTER 2012).

Studies evaluating toxicity on different larval ages can provide information on the optimal timing of entomopathogenic bacterial application in the field. In this context, the research aimed to assess the susceptibility of caterpillars of different ages of $A$. ipsilon to commercial formulations Agree $^{\circledR}(B$. thuringiensis var. aizawai GC-91) and Dipel ${ }^{\circledR}$ (B. thuringiensis var. Kurstaki lineage HD-1).

For the experiments, an $A$. ipsilon rearing was established at the Laboratório de Entomologia (NUDEMAFI) of the Universidade Federal do Espírito Santo (UFES/CCAE). The insects were provided by the Núcleo de Estudos em Manejo Integrado de Pragas Agrícolas (AGRIMIP) of the Universidade Estadual Paulista Júlio de Mesquita Filho (UNESP/Botucatu). The insect multiplication was carried out in an airconditioned room, with a temperature of $25 \pm 1 \stackrel{\circ}{\circ}$, RH $70 \pm 10 \%$ and photophase of $14 \mathrm{~h}$. Adult moths were placed in PVC cages $(25 \mathrm{~cm}$ diameter $\times 25 \mathrm{~cm}$ height). The inside of the cages was paper coated, the top end was closed with a paper towel, and the bottom end was covered with paper styrofoam sheet $(25 \times 25 \times 3$ $\mathrm{cm}$ thickness). The moths were fed with a solution of honey (10\%). The paper covering the cages and containing the oviposition's moth was packed in plastic pots $(1 \mathrm{~L})$. After hatching, the caterpillars were transferred into $50 \mathrm{ml}$ plastic pots. The caterpillars were fed an artificial diet, developed by GREENE et al. (1976). Nine-day-old caterpillars were individualized in plastic containers (3 $\mathrm{cm}$ in diameter) and supplied with the diet until the pupal stage. The pupae were transferred to acrylic cages $(50 \times 50 \times 50 \mathrm{~cm})$ until adult emergence.

Two bioinsecticides were used in the toxicity tests of $B$. thurigiensis to $A$. ipsilon. Agree ${ }^{\circledR}$ biopesticide was formulated based on $B$. thuringiensis var. aizawai GC-91 and was purchased from Bio Controle Métodos de Controle de Pragas Ltda. (lot 002-15-8.600). Dipel WP ${ }^{\circledR}$ biopesticide was formulated based on $B$. thuringiensis var. kurstaki lineage $\mathrm{HD}-1$ and was purchased from Sumitomo Chemical do Brasil Representações Ltda. (lot 026-13-4106).

In the toxicity bioassay, the bioinsecticides were diluted in sterile distilled water, and the concentration was adjusted to $1 \times 10^{8}$ spores $\mathrm{mL}^{-1}$ with the aid of the Neubauer ${ }^{\circledR}$ chamber and optical microscope. Acrylic tubes $(3 \mathrm{~cm}$ height $\times 2 \mathrm{~cm}$ diameter) were filled to $1 / 4$ of the volume with the artificial diet described earlier. An aliquot of $50 \mu \mathrm{L}$ of the solution containing $1 \times 10^{8}$ spores $\mathrm{mL}^{-1}$ was pipetted onto the diet. One caterpillar was inoculated into each tube. The caterpillars used in the bioassays were five different ages (0-24, 48-72, 96$120,144-168$, and 192-216 h). For each treatment, 50 caterpillars were used, of which each group of 10 caterpillars corresponded to one repetition, making five replications with 10 caterpillars each. The same procedure was performed for control. However, sterile distilled water was used on a diet. The experiment was maintained in an air-conditioned room $\left(25 \pm 1{ }^{\circ} \mathrm{C}, \mathrm{RH} 70 \pm 10 \%\right.$ and photophase $\left.14 \mathrm{~h}\right)$. The number of dead caterpillars was accounted for on the seventh day, and the data were transformed for percentage.

The bioassay was conducted in a completely randomized design, in factorial scheme 3 (bioinsecticides + control) $\times 5$ (ages of caterpillars). Mortality data were submitted to analysis of variance, and the means were compared by the Tukey test $(p<0.05)$ using software $R(R$ DEVELOPMENT CORE TEAM 2017).

A bioassay to estimate the lethal concentration $\left(\mathrm{LC}_{50}\right.$ and $\mathrm{LC}_{90}$ ) was performed on $0-24 \mathrm{~h}$ old caterpillars, the only age of caterpillars that resulted in mortality above $90 \%$. The experimental conditions were the same as in the previous bioassay. For each biopesticide, ten equidistant spaced concentrations were used using a logarithmic scale, from $1 \times 10^{4}$ spores. $\mathrm{mL}^{-1}$ to $1 \times 10^{8}$ spores. $\mathrm{mL}^{-1}$. For the control, sterile distilled water was used. The bioassay was repeated twice in time. The caterpillars were kept in an airconditioned room ( $25 \pm 1 \stackrel{\circ}{\circ}, 70 \pm 10 \% \mathrm{RH}$, and photophase $14 \mathrm{~h}$ ). The mortality of caterpillars was evaluated daily for seven days. The lethal concentrations were estimated using the Probit analysis through Polo-PC software (Probit Analysis), as HADDAD et al. (1995).

The data from the variance analysis revealed a significant effect of the bioinsecticides $\times$ caterpillar age factors $(p<0.01)$ for larval mortality (Table 1$)$, thus proceeding the unfolding of the interaction. 
Table 1. Summary table for analysis of variance in mortality data of different larval ages of Agrotis ipsilon by Bacillus thuringiensis based bioinsecticides.

\begin{tabular}{llll}
\hline Source of Variation & $\mathrm{DF}^{1}$ & $\mathrm{MS}^{2}$ & $p^{3}$ \\
\hline Bioinsecticides & 2 & 11951.50 & 0.0 \\
Larval age & 4 & 11327.30 & 0.0 \\
Bioinsecticides * Larval age & 8 & 2994.20 & 0.0 \\
\hline
\end{tabular}

$\mathrm{CV}^{4}: 31,99 \%$

$\mathrm{DF}=$ Degree of freedom; ${ }^{2} \mathrm{MS}=$ Mean square; ${ }^{3} p=$ Significance level $(\mathrm{p}<0.01) ;{ }^{4} \mathrm{CV}=$ Coefficient of Variation.

Mortality was inversely proportional to the age of caterpillars, with higher mortality in younger caterpillars (Table 2). There was no difference in mortality of caterpillars with $0-24 \mathrm{~h}$ between Agre ${ }^{\circledR}$ and Dipe $^{\circledR}$ bioinsecticides, with 98 and $95.7 \%$ mortality, respectively (Table 2). At age $48-72 \mathrm{~h} \mathrm{Agree}{ }^{\circledR}$ bioinsecticides presented $84 \%$ mortality and differed from Dipe ${ }^{\circledR}$ with $61 \%$. For both evaluated bioinsecticides the mortality was less than $12 \%$ from $144-168 \mathrm{~h}$ of the age of the caterpillars (Table 2).

Table 2. Mortality (\%) of different larval ages of Agrotis ipsilon by bioinsecticides based on Bacillus thuringiensis.

\begin{tabular}{lccccc}
\hline & \multicolumn{5}{c}{ Larval age (hours) } \\
\cline { 2 - 5 } Treatment & $0-24$ & $48-72$ & $96-120$ & $144-168$ & $192-216$ \\
\hline Control $_{\text {Dipel }}^{(8)}$ & $0.0 \mathrm{Ab}$ & $8.0 \mathrm{Ac}$ & $2.0 \mathrm{Ab}$ & $2.0 \mathrm{Aa}$ & $4.0 \mathrm{Aa}$ \\
Agree $^{(\otimes)}$ & $95.7 \mathrm{Aa}$ & $61.1 \mathrm{Bb}$ & $8.2 \mathrm{Cab}$ & $12.0 \mathrm{Ca}$ & $12.0 \mathrm{Ca}$ \\
& $98.0 \mathrm{Aa}$ & $84.0 \mathrm{Aa}$ & $20.2 \mathrm{Ba}$ & $4.0 \mathrm{Ca}$ & $12.0 \mathrm{BCa}$ \\
\hline
\end{tabular}

Means followed by the same uppercase in the rows and lowercase in the column do not differ statistically by the Tukey test $(\mathrm{p}<0.01)$.

The caterpillars of $0-24 \mathrm{~h}$ of age presented mortality above $90 \%$ (Table 2) and were submitted to bioassays to estimate the lethal concentration $\left(\mathrm{LC}_{50}\right.$ and $\left.\mathrm{LC}_{90}\right)$. In the estimation of $\mathrm{LC}_{50}$ and $\mathrm{LC}_{90}$, the increase in spore concentrations provided an increase in insect mortality, thus establishing an increasing relation between spore concentration and the number of dead caterpillars (Table 3). The response curve between concentration and mortality for the Agree ${ }^{\circledR}$ biopesticide showed a higher slope compared to Dipel ${ }^{\circledR}$ (1.46 and 1.27, respectively) (Table 3).

Table 3. Susceptibility Agrotis ipsilon to Bacillus thuringiensis based bioinsecticides. Insect age 0-24 hour.

\begin{tabular}{|c|c|c|c|c|c|c|}
\hline Biopesticide & $\mathrm{N}^{1}$ & $\mathrm{DF}^{2}$ & Slope $\pm \mathrm{SE}^{3}$ & $\mathrm{LC}_{50}(\mathrm{Cl} 95 \%)$ & $\mathrm{LC}_{90}(\mathrm{Cl} 95 \%)$ & $x^{2}$ \\
\hline Agree $^{(}$ & 556 & 5 & $1.46 \pm 0.14$ & $\begin{array}{c}9.8 \times 10^{5} \\
\left(6.3 \times 10^{5}-1.4 \times 10^{6}\right)\end{array}$ & $\begin{array}{c}7.4 \times 10^{6} \\
\left(4.7 \times 10^{6}-1.4 \times 10^{7}\right)\end{array}$ & 5.7 \\
\hline Dipel $^{(B)}$ & 667 & 6 & $1.27 \pm 0.11$ & $\begin{array}{c}1,3 \times 10^{6} \\
\left(9.9 \times 10^{5}-1.8 \times 10^{6}\right)\end{array}$ & $\begin{array}{c}1.4 \times 10^{\prime} \\
\left(9.8 \times 10^{6}-2.2 \times 10^{7}\right)\end{array}$ & 3.9 \\
\hline
\end{tabular}

${ }^{T} \mathrm{~N}=$ number of observations; ${ }^{2} \mathrm{DF}=$ Degrees of freedom; ${ }^{3}$ Slop $\pm \mathrm{EP}=$ Curve slope \pm standard error; $\mathrm{LC}=$ Lethal concentration (spores. $\left.\mathrm{mL}^{-1}\right) ; \mathrm{Cl}=$ Confidence interval $(\mathrm{p}<0.05) ; \mathrm{X}^{2}=$ Chi-square.

The lethal concentration required to cause mortality in 50 and $90 \%$ of the population of $A$. ipsilon was, respectively, $9.8 \times 10^{5}$ and $7.4 \times 10^{6}$ spores $\mathrm{mL}^{-1}$ for Agree ${ }^{\circledR}$ and $1.3 \times 10^{6}$ and $1.4 \times 10^{7}$ spores $\mathrm{mL}^{-1}$ for Dipel ${ }^{\Theta}$ (Table 3). As there was no difference, verified by the confidence interval between $\mathrm{LC}_{50}$ and $\mathrm{LC}_{90}$ values, the ratio between Dipel ${ }^{\circledR}$ and $A g r e{ }^{\circledR}$ was 1.33 and 1.89 for $L C_{50}$ and $L C_{90}$, respectively (Table 3).

At age 0-24 h, mortality was greater than $95 \%$ for the two bioinsecticides. Generally, early-stage caterpillars are more susceptible to $B$. thuringiensis when compared to older caterpillars, as observed in Plutella xylostella (Linnaeus) (Lepidoptera: Plutellidae), Chilo suppressalis (Walker) (Lepidoptera: Crambidae) and Scirpophaga incertulas (Walker) (Lepidoptera: Pyralidae) (ALINIA et al. 2000, MORAES \& FOERSTER 2012). In the evaluated ages of 144-168 and 192-216 h, no difference was observed between the bioinsecticides and the control, demonstrating that the bioinsecticides have low efficiency at such ages. The low mortality of caterpillars of advanced ages may be related to some mechanism in the immune system that affects the degree of susceptibility to Bt (EL AZIZ \& AWAD 2010, BINNING et al. 2015, WANG et al. 2015). This defense mechanism can be attributed to habits, physiological, and biochemical changes, which can significantly alter the binding ability of Bt toxins in the mesentery (ABDULLAH et al. 2009, WANG et al. 2015). 
The higher slope of the curve presented by the Agree ${ }^{\circledR}$ over Dipe ${ }^{\circledR}$ shows that small variations in the concentration of the bioinsecticide can promote significant changes in the mortality of caterpillars. This variation indicates that the insect population used in the lethal concentration bioassay responded more homogeneously to Agree ${ }^{\circledR}$ when compared to the Dipel ${ }^{\circledR}$. Generally, different formulations of Bt-based bioinsecticides can cause different mortality rates in the same population of a specific insect species (GONÇALVES 2015). Also, bioinsecticides have different strains of Bt and Cry toxins that can influence the mortality of $A$. ipsilon (MENEZES et al. 2010). Agree ${ }^{\circledR}$ has the toxins Cry 1Ac, 1C, 1D, and 2, while the Dipel ${ }^{\circledR}$ biopesticide has the toxins Cry $1 \mathrm{Ab}, 1 \mathrm{Aa}, 1 \mathrm{Ac}$, and 2 (GONÇALVES 2015). The reason for the Agree ${ }^{\circledR}$ biopesticide has shown more significant potential in the case of Dipel ${ }^{\circledR}$ may be in the composition of its toxins. However, it is not possible to say which toxins are more toxic to $A$. ipsilon because there are still no studies of the effects of each Cry toxin (MENEZES et al. 2010).

The results found in this study demonstrate that both $B$. thuringiensis based bioinsecticides demonstrate potential for control the A. ipsilon caterpillar. Bt toxicity is higher in younger caterpillars. New bioassays with biopesticides in the field under different environmental conditions, as well as selectivity bioassays to natural enemies, are valuable for the establishment of a biological management program for $A$. ipsilon.

\section{ACKNOWLEDGEMENTS}

The authors would like to thank the Coordination for the Improvement of Higher Education Personnel (CAPES), to Espírito Santo Research Foundation (FAPES), and to the National Council for Scientific and Technological Development (CNPq) for financial support.

\section{REFERENCES}

ABDULLAH MAF et al. 2009. Manduca sexta (Lepidoptera: Sphingidae) cadherin fragments function as synergists for Cry $1 \mathrm{~A}$ and Cry1C Bacillus thuringiensis toxins against noctuid moths Helicoverpa zea, Agrotis ipsilon and Spodoptera exigua. Pest Management Science 65: 1097-1103.

ALINIA F et al. 2000. Effect of Plant Age, Larval Age, and Fertilizer Treatment on Resistance of a cry1Ab-Transformed Aromatic Rice to Lepidopterous Stem Borers and Foliage Feeders. Journal of Economic Entomology 93: 484-493.

BINNING RR et al. 2015. Susceptibility to Bt proteins is not required for Agrotis ipsilon aversion to Bt maize. Pest Management Science 71: 601-606.

BOUGHTON AJ et al. 2001. Potential of Agrotis ipsilon nucleopolyhedrovirus for suppression of the black cutworm (Lepidoptera: Noctuidae) and effect of an optical brightener on virus efficacy. Journal of economic entomology 94: 1045-1052.

EL AZIZ NMA \& AWAD HH. 2010. Immune Response in Agrotis ipsilon (Lepidoptera; Noctuidae) induced by Bacillus thuringiensis and Dimilin. Egyptian Journal of Biological Pest Control 20: 7-13.

FERNANDES FL et al. 2013. Damage of Agrotis ipsilon (Lepidoptera: Noctuidae) on Coffea arabica in Brazil. Revista Colombiana de Entomología 39: 49-50.

GONÇALVES KC. 2015. Mortalidade e efeitos subletais de Bacillus thuringiensis Berliner em Spodoptera albula (Walker, 1857). Dissertação (Mestrado em Entomologia Agrícola). Jaboticabal: UNESP. 30p.

GREENE GL et al. 1976. Velvetbean caterpillar: a rearing procedure and artificial medium. Journal of Economic Entomology 69: 487-488.

HADDAD ML et al. 1995. Programa MOBAE: Modelos bioestatísticos aplicados à entomologia (software). Piracicaba: USP. 44p.

IBRAHIM MA et al. 2010. Bacillus thuringiensis. Bioengineered Bugs 1:31-50.

$\mathrm{LI} F$ et al. 2002. Effects of Bt on respiration of the larvae of Agrotis ypsilon (Rottemberg). Natural Enemies of Insects 24: 15-19.

LINK D \& COSTA EC. 1984. Comportamento larval da lagarta-rosca, Agrotis ipsilon (Hufnagel, 1767). Revista do Centro de Ciências Rurais 14: 191-199.

MENEZES RS et al. 2010. Seleção e caracterização de estirpes de Bacillus thuringiensis tóxicas a Agrotis ipsilon. Universitas: Ciências da Saúde 8: 1-13.

MORAES CP \& FOERSTER LA. 2012. Toxicity and residual control of Plutella xylostella L. (Lepidoptera: Plutellidae) with Bacillus thuringiensis Berliner and insecticides. Ciência Rural 42: 1335-1340.

PARRA JRP et al. 2002. Controle biológico no Brasil: parasitoides e predadores. São Paulo: Manole. 635p.

R DEVELOPMENT CORE TEAM. 2017. R: A language and environment for statistical computing. Vienna: R Foundation for Statistical Computing.

SANAHUJA G et al. 2011. Bacillus thuringiensis: a century of research, development and commercial applications. Plant Biotechnology Journal 9: 283-300.

WANG Y et al. 2015. Different Effects of Bacillus thuringiensis Toxin Cry1Ab on Midgut Cell Transmembrane Potential of Mythimna separata and Agrotis ipsilon Larvae. Toxins 7: 5448-5458. 